UDC: 811.111'373.45:811.112.5

D0I: https://doi.org/10.18485/philologia.2018.16.16.4

\title{
- THE ROLE OF ORTHOGRAPHY AND PHONEME INVENTORY IN DUTCH STUDENTS' SPEECH PERCEPTION IN THE EFL CLASSROOM
}

MARLISA HOMMEL ${ }^{1}$

University of Utrecht

Cilj ovog rada je dvojak: da se odredi da li ortografija odmaže percepciji L2 kod učenika i da li, kao što PAM-L2 predviđa, fonemski inventar u L1 utiče na L2 govor holandskih srednjoškolaca. Najpre je sproveden pilot test kako bi se utvrdilo da li je teže opaziti 'nove' glasove, koji ne postoje u fonemskom inventaru holandskog, od 'istih' glasova. Nakon toga je sproveden još jedan test percepcije koji je ispitao da li ortografija otežava percepciju fonema ili grupa fonema koje su teške holandskim učenicima. U tom testu svi glasovi su se našli u frekventnim engleskim rečima i činili su izgovorene stimuluse, a pisane reči-mete su bile ili reči čiji pisani oblik odgovara auditorno percipiranim rečima, ili reči čiji se pisani oblik razlikuje od auditorno percipirane reči. Rezultati upućuju na to da ortografija otežava percepciju. Povrh toga, u skladu sa predviđanjima PAM-L2, 'nove' L2 glasove je teže percipirati od 'istih' glasova.

Ključne reči: perceptivno učenje, veliki fonemski inventar, holandski, engleski, ortografija.

\section{INTRODUCTION}

Learning a second or foreign language in school is often a laborious task. It comprises many aspects such as productive skills (speaking and writing), perceptive skills (listening and reading comprehension) and learning vocabulary and grammar rules. These language skills are related. Arguably the hardest to master are listening and speaking skills, because sounding native-like is strongly correlated with Age of Learning and these skills are online with little time for the learners to monitor their response (Flege et al. 1995). An adult language learner does not learn a foreign

1 Contact information: m.p.hommel@uu.nl 
language in school by auditory input only, but also by orthographic input. This visual orthographic input can help or hinder the perception and production of $\mathrm{L} 2$ sounds. For example, Dutch does not have English $/ \delta /$ and $/ \theta /$ in its phoneme inventory, nor does it have the 'th' in its orthography and language learners will quickly realise that the English 'th' represents a new sound. In this instance, orthography may help the language learner. On the other hand, orthography can confuse the language learner. For example, the English written '-ough' is pronounced differently in 'tough' / $\mathrm{t} \Lambda \mathrm{f} /$, 'though' /ðә৩/ and 'through' / $\theta$ ru:/. Some languages have a high degree of graphemephoneme correspondence, making the orthography of these languages transparent. A study that looked at the role of orthography on the perceptual accuracy of speech sounds found that a language with transparent orthography has a facilitating effect on speech perception (Erdener and Burnham 2005). In the case of English /æ/-/e/2 ('man''men'), Escudero et al. (2008) showed a facilitating effect of orthography of this English minimal pair for Dutch listeners. Many studies, however, found that orthography can hamper the "establishment of second language phonological categories" (Rafat 2011: iii, see also Bassetti et al. 2015 and Ziegler \& Ferrand 1998). Silveira (2007), for instance, found a negative effect of English orthography on English pronunciation by ten Brazilian speakers. An opaque orthography or an "inconsistent spelling-to-sound mapping" in a language negatively influences word perception of that language (Ziegler \& Ferrand 1998: 683). Aside from a few exceptions (such as /æ/-/e/), English has an opaque orthography which causes English children learning to read to lag behind in phoneme awareness compared to, for example, German or Dutch children as the latter languages have more transparent orthographies (Goswami et al. 2005). Orthography does not only influence phoneme awareness, but it is reciprocal: phoneme awareness also influences orthography (Patel et al. 2004). Because Dutch L1 speakers cannot readily apply their phoneme awareness to the opaque English orthography, it is expected that Dutch listeners are distracted by inconsistent sound-to-spelling mappings in English speech perception. This is the first question we will try to answer: does orthography play a negative role in $\mathrm{L} 2$ auditory speech perception?

Besides the role of orthography on L2 speech perception, we will look at the role of the L1 phoneme inventory on L2 speech perception. In order to do so, this paper evaluates predictions made by the Perceptual Assimilation Model (PAM). This speech perception model was proposed by Best (1995) and claims that naïve listeners perceive sound contrasts in different ways. The model has been adapted for adult L2 learners, PAM-L2 (Best \& Tyler 2007). It postulates that the L1 filters how L2 sounds are perceived. When a non-native sound contrast is perceived as an existing sound contrast in the native phoneme inventory, native listeners discriminate this non-native contrast well (two-category assimilation). When a non-native sound contrast is perceived as belonging to only one sound in the native phoneme inventory, native listeners struggle to perceive this non-native contrast well. There are two ways that a non-native contrast is assimilated to a single phoneme: both sounds of a non-native sound contrast are perceived as good or poor exemplars of a single native phoneme (single-category assimilation), or one non-native sound is considered a better exemplar of the native

2 When referring to the DRESS vowel in this paper, RP symbol /e/ is used as opposed to GA / $\varepsilon /$ (Wells, 1982). 
phoneme than the other (category goodness difference). In terms of perception, the two-category (TC) assimilation is perceived best by $L 2$ listeners, followed by the category goodness (CG) and the single-category (SC) assimilation is most poorly perceived (TC > (G > SC) (Best 1995).

Applying PAM-L2 to this study, the model predicts that 'new' English sounds are poorer perceived by Dutch listeners than sounds that already exist in the Dutch phoneme inventory (Best \& Tyler 2007). Two-category assimilation (for example L2 English /I/-/i/ is perceived as L1 Dutch /I/-/i/) is best perceived by L2 listeners, followed by one category assimilation (for example L2 English /æ/-/e/ are both perceived as L1 Dutch $/ \varepsilon /$ ). In this paper, we do not distinguish between (G and SC and consider both categories as 'new' sounds and the TC as 'same' sounds because linguistic contexts in which phonemes are embedded can change vowel realisation to such extent that the listener may perceive it as either CG or SC (Strange et al. 2001). The second question we will try to answer is: do Dutch students perceive English 'same' sounds better than 'new' sounds?

\section{PILOT PERCEPTION TASK TO EVALUATE PAM-L2}

In a previous study (Hommel 2017), an auditory speech perception pilot was conducted to see which English phonemes are difficult for Dutch students to perceive. Out of an identification task with 109 different phonemes and phoneme clusters, thirtyeight speech sounds that were poorly perceived by Dutch listeners were identified (see Table 1 below). A new test was created based on the results of the pilot, which consisted solely of these 38 constituents. This test involved not only auditory words but also written words (whereas the pilot only involved written letters representing sounds). Students would hear a word, e.g. 'push' and saw four options written on a screen: 'cook', 'cope', 'cow' and 'coup'. Students had to choose what sound they had heard in the auditory target by clicking on the word with underlining in the same position as the corresponding target sound, which could be in any position (onset, nucleus or coda). The correct answer in this example was 'cook' because both 'push' and 'cook' have the $\mathrm{v} /$-sound in the underlined position. Had the response options been heard instead of written, it would have asked too much of the auditory working memory of the student. In addition, the test was deemed too easy if the auditory word would be the same as the written target answer (e.g. if 'push' was heard and 'push' would be the written answer). 


\begin{tabular}{|c|c|c|}
\hline Onset & Nucleus & Coda \\
\hline$/ \mathrm{j} /$ & $/ \mathrm{p} /$ & $/ \theta /$ \\
\hline$/ \mathrm{v} /$ & $/ \mho /$ & $/ g /$ \\
\hline$|z|$ & /ov/ & $/ \mathrm{t} /$ \\
\hline$/ \mathrm{d} /$ & $/ \Lambda /$ & $/ \mathrm{d}_{3} /$ \\
\hline$/ 1 /$ & $/ \mathrm{I} /$ & $|z|$ \\
\hline$/ g /$ & /e/ & $/ \mathrm{s} /$ \\
\hline$/ \mathrm{f} /$ & $/ 0 /$ & $/ \mathrm{f} /$ \\
\hline$/ \mathrm{d}_{3} /$ & $/ \mathrm{i} /$ & $/ \mathrm{tg} /$ \\
\hline$/ \mathrm{s} /$ & /eI/ & $/ \mathrm{k} /$ \\
\hline /ठ/ & $/ \mathrm{u} /$ & $/ \mathrm{v} /$ \\
\hline$/ \mathrm{r} /$ & $/ \mathfrak{~ / ~}$ & $/ \mathrm{d} /$ \\
\hline$/ \theta /$ & & $\mid g /$ \\
\hline$/ \mathrm{b} /$ & & $|3|$ \\
\hline & & $/ \partial /$ \\
\hline
\end{tabular}

Table 1. Difficult English sounds by phonological position

We looked at students' average score per speech sound in this task to compare 'new' with 'old' sounds. However, it is debatable which English sound is considered 'new' for Dutch listeners. PAM uses the International Phonetic Alphabet (IPA) as a basis for determining a 'new' or 'same' sound, which can be unreliable (Rochet 1995). Therefore, in addition to using IPA to decide whether an English sound is 'new' or not for Dutch native listeners, we also consulted English and Dutch vowel and consonant charts as phoneme realisations can differ despite sharing the same IPA symbol (see e.g. Levy \& Law 2010). These charts represent the acoustic realisations of phonemes. Vowel charts show that Dutch / $\varepsilon$ / differs from English /e/ Gussenhoven 1999: 76 for the Dutch chart and Roach 2004: 242 for the BrE chart). They also show that Dutch $/ \mathrm{s} /$ has a very different realisation than the English / $\mathrm{s}$ // which is why this nucleus is also considered 'new' to Dutch L1 speakers. Concerning consonants, /3/ is an uncommon sound in Dutch (e.g. in the French loan word baggage [ba'xa:32] 'luggage'). However, /3/ in coda position is rare in English too and occurs, similar to Dutch, in French loan words (e.g. beige [be 3 ]]). When comparing the Dutch and English IPA charts and adding English $/ \mathrm{s}: /$, eleven of the 29 constituents have no direct Dutch counterpart, namely consonant (clusters) $/ \mathrm{t} / \mathrm{l} / \mathrm{d} 3 /, / \theta /$ and $/ \delta /$ and nuclei $/ \mathrm{p} /, / v /, / \partial v /, / \Lambda /, / æ /, / \mathrm{e} /$ and $/ \mathrm{o}: /$ (Mees \& Collins 2003). Linguistic contexts in which phonemes are embedded can change vowel realisation to such extent that the listener will perceive it as either CG or SC (Strange et al. 2001). 
It should be noted that "neither very abstract phonological descriptions of phoneme inventories nor acoustic comparisons of specific realizations of phoneme categories will be adequate in predicting cross-language perceptual similarities"; whether an L2 sound is perceived as 'same' or 'new' changes depending on the context that the sound is in (ibid: 1703). The pilot contained no orthography, making it easier to determine whether a sound is perceived as 'same' or 'new'.

\section{METHOD}

For evaluating PAM-L2, students' perception scores on the pilot perception task were used. Out of the 38 difficult sounds (see Table 1), nine sounds occur in both onset and coda position, leaving 29 different constituents. In order to establish whether Dutch listeners perceive 'new' sounds $(/ \mathrm{t} \mathrm{J} /, / \mathrm{d} 3 /, / \theta /, / \delta /$ and nuclei $/ \mathrm{p} /, / \mathrm{v} /, / \partial v /, / \Lambda /, / æ /$, /e/ and /o:/) more poorly than 'same' sounds (/1/, /f/, /v/, /s/, /z/, /s/, /3/, /r/, /b/, /j/, /t/, /d/, $/ \mathrm{k} /, \mathrm{g} /$, and nuclei /I/, /i:/, /er/ and /u:/), perception scores of 'new' sounds in the pilot were compared to 'same' sounds using an independent t-test. Students' perception scores from the pilot were used ( $N=50, M=19$ years, $S D=2.1$ years), see Appendix $A$ for mean scores per constituent.

For evaluating whether English orthography plays a negative role in $L 2$ auditory speech perception, another speech perception task was conducted. We call this the main test as the number of participants was much higher $(N=125)$ than the pilot described in section two $(\mathrm{N}=50)$. Students' average perception scores on sounds with a difficult orthography were compared to test scores on sounds with an easy orthography. Words were considered to have a difficult or opaque orthography where the orthography of the spoken word differed from that of the written word being the correct response. For example, target nucleus / $/ \mathrm{w}$ was seen as difficult because the $/ \mathrm{v} /$ in 'push' differed in orthography from the correct answer 'cook' (see Table 2). Next, words were considered to have a difficult or opaque orthography where the target answer was similar to a distractor. For example, target nucleus $/ \Lambda$ / was seen as difficult because the $/ \Lambda$ / in correct 'butt' is similar in orthography to the incorrect foil 'pulll' (see table 3). Independent t-tests were performed to see whether orthography influences listeners' speech perception. Students' perception scores on the main test were used ( $N=125, M$ $=19$ years, $S D=1.3$ year .

The main test was not used for evaluating PAM-L2 as many of the new sounds also contained target sounds with different orthography (namely $/ \mathrm{d}_{3} /, / \mathrm{v} /$ and $/ \mathrm{o}: /$, see table 2) or good distractors with similar orthography (namely $/ \theta /, /$ ov/, $/ \Lambda /$ and $/ æ /$, see table 3), which is a confounding factor. If new sounds were to score significantly lower than familiar/same sounds, then this could be due to orthography rather than new vs. same sounds. The pilot contains little to no orthography, making it more suitable to evaluate PAM-L2. The 'new' sound coda /ð/ did not occur in the pilot. 


\section{RESULTS}

\subsection{ORTHOGRAPHY}

In the main test, six out of thirty-eight target words contained a different orthography to the spoken word (see Table 2). These six words ( $M=45 \%, S D=28.4 \%$ ) scored significantly lower compared to the target sounds with similar orthography $(\mathrm{N}=$ $32, M=71 \%, S D=24.6 \%), t(36)=-2.31, p=.03$. The effect size $(d=0.97)$ signifies a large difference (Becker 2000). These six target sounds that contained a different orthography were excluded. Next, we looked at foils that contained similar orthography to the spoken words (i.e., good distractors) and they were compared to average perception scores on the remaining sounds (see table 3 ). Results show that foils with similar orthography confused the listeners more $(N=11, M=56 \%, S D=28.6 \%)$ than others $(N=21, M=78 \%$, $\mathrm{SD}=18.8 \%), t(30)=-2.62, p=.01$. The effect size $(d=.91)$ signifies a large difference (Becker 2000).

Because the result suggests that orthography hampers perception and there is little to no orthography in the pilot, one would expect the scores in the pilot to be higher than the scores in the main test. However, this is not the case. Average scores in perception seem very comparable $71 \%$ in the pilot vs. $74 \%$ in the main test in onsets, $62 \%$ vs. $57 \%$ in nuclei and $68 \%$ vs. $67 \%$ in codas respectively).

\begin{tabular}{c|c|c}
\hline Target sound & Auditory word & Written target \\
\hline /o/ & Push & Cook \\
/s:/ & Thought & Paw \\
/i:/ & Deal & Keep \\
/-d3/ & Age & Judge \\
/dz-l & Gym & Duke \\
/-s/ & Face & Mess \\
\hline
\end{tabular}

Table 2. English auditory words with target answers with a different orthography 


\begin{tabular}{|c|c|c|}
\hline Target sound & Written target & Foil \\
\hline$|-\theta|$ & Oath & Clothe \\
\hline |əu| & Poke & Pot \\
\hline$|\Lambda|$ & But & Pull \\
\hline $\mid \mathrm{I} /$ & Bit & Bite \\
\hline$|-z|$ & His & Kiss \\
\hline |er/ & Cape & Scalp \\
\hline /u:/ & Boot & Book \\
\hline$|æ|$ & Cap & Cape \\
\hline /ð-। & Though & Thief \\
\hline$|\theta-|$ & Theme & These \\
\hline |-ð| & Sunbathe & Beneath \\
\hline
\end{tabular}

Table 3. English written target answers with good distractors

\subsection{NEW VS. SAME SOUNDS}

In order to establish whether Dutch listeners perceive 'new' sounds more poorly than 'same' sounds, perception scores on the pilot were compared. Results show that 'new' sounds ( $\mathrm{N}=12, \mathrm{M}=56 \%, \mathrm{SD}=22.6 \%$ ) were harder to perceive than 'same' sounds $(\mathrm{N}=22, \mathrm{M}=74 \%, \mathrm{SD}=18.7 \%), t(32)=-2.54, p=.02$. The effect size $(d=.87)$ signifies a large difference (Becker 2000).

\section{DISCUSSION AND CONCLUSION}

In this paper we looked at two hypotheses: (1) that opaque orthography impedes perception and (2) that, in accordance with many other studies (e.g. Kartushina et al. 2015; Levy \& Law 2010 and Tyler et al, 2014), 'new' sounds are more difficult to perceive than 'same' sounds, and that this still holds for a classroom setting. Both hypotheses were confirmed. Results suggest that orthography impedes perception but that linguistic context (i.e. using stimuli in words instead of isolated stimuli) may facilitate perception. Listening to L2 phonemes embedded in a linguistic context (in the main test this context was a high frequency word) helps the language learner in forming new phoneme categories (Strange et al. 2001). Phonemes are pronounced differently depending on the context due to co-articulation, and the context is one of the factors 
that determine how difficult the sound is to perceive for a language learner (ibid). Therefore, the ecological validity of the task (i.e. using high-frequency words) seems to justify the use of phonemes in a linguistic context as opposed to a task where these phonemes only occur in isolation.

When a sound is absent in the Dutch phoneme inventory (a 'new' sound), it is difficult for Dutch listeners to perceive this sound well. When looking at the perception score of each individual phoneme, however, not all 'new' sounds were hard to perceive. For example, the 'new' sounds /æ/ and /e/ were not poorly perceived and the 'new' sound /v/ was not perceived worse than 'same' (but still differing acoustically) sound /u:/. It is possible that speech perception is influenced by statistical learning, where new L2 sounds which are more frequent are learned earlier and/or better as they are more salient in the L2 (Mines et al. 1978). Because certain contrasts are more frequent than others, it is especially important for language learners to correctly discern the most common contrasts. For example, English /æ/-/e/ is more frequent than the minimal pair / / //u:/, making the former contrast more salient. Not surprisingly, Dutch students correctly identified both /æ/ and /e/ better than /v/ and /u:/. Similarly, Dutch students perceived both $/ v /$ and $/ u$ :/ better than less common $/ \theta /$ and $/ \delta /$, perhaps due to salience or statistical learning. Phoneme $/ \theta /$ is more frequent and less marked than voiced / $/ /$

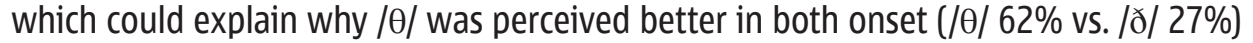
and coda position (/ $\theta / 65 \%$ vs. /ð/6\%).

Results found here are tentative. To have more robust evidence that orthography influences listeners' speech perception, the same stimuli should be tested with auditory stimulithatboth differin and share the same orthography with the written target answer, not with either or. In addition, another confounding factor is that 'new' sounds are perceptually more difficult than 'same' sounds. Future research looking at the role of orthography in L2 speech perception should take into account the factor of 'new' and 'same' sounds.

\section{ACKNOWLEDGMENTS}

This work is part of the Doctoral Grant for Teachers with project number 023.007.008, which is financed by the Netherlands Organisation for Scientific Research (NWO). I would like to thank my supervisors René Kager and Willemijn Heeren for their time and their valuable suggestions.

\section{REFERENCES}

Bassetti, B., P. Escudero \& R. Hayes-Harb. 2015. Second Language Phonology at the Interface between Acoustic and Orthographic Input. Applied psycholinguistics 36 (1), 1-6.

Becker, L. 2000. Effect Size Calculators. [Internet]. Available at: http://www.uccs.edu/ Ibecker/index.html [30.01.2018].

Best, C. T. 1995. A Direct Realist View of Cross-Language Speech Perception. In W. Strange (ed.) Speech Perception and Linguistic Experience: Theoretical and Methodological Issues in Cross-language Speech Research. York: Timonium, 171-204. 
Best, C. T. \& M. D. Tyler. 2007. Nonnative and Second-language Speech Perception: Commonalities and Complementarities. In 0. S. Bohn \& M. J. Munro (eds.) Language Experience in Second Language Speech learning: In honor of James Emil Flege. Amsterdam: John Benjamins Publishing, 13-34.

Cutler, A. et al. 2004. Patterns of English Phoneme Confusions by Native and Non-native Listeners. JASA 116 (6), 3668-3678.

Erdener, V. D. \& D. K. Burnham. 2005. The Role of Audiovisual Speech and Orthographic Information in Nonnative Speech Production. Language Learning 55, 191-228.

Escudero, P., R. Hayes-Harb \& H. Mitterer. 2008. Novel L2 Words and Asymmetric Lexical Access. Journal of Phonetics 36, 345-360.

Escudero, P., E. Simon \& H. Mitterer. 2012. The Perception of English Front Vowels by North Holland and Flemish Listeners: Acoustic Similarity Predicts and Explains Cross-linguistic and L2 Perception. Journal of Phonetics 40 (2), 280-288.

Flege, J. E. 1992. The Intelligibility of English Vowels Spoken by British and Dutch Talkers. Intelligibility in speech disorders: Theory, measurement, and management 1, 157-232.

Flege, J. E. \& W. Eefting. 1987. Cross-language Switching in Stop Consonant Perception and Production by Dutch Speakers of English. Speech Communication 6 (3), 185-202.

Flege, J. E., M. J. Munro \& I. R. MacKay. 1995. Factors Affecting Strength of Perceived Foreign Accent in a Second Language. JASA 97 (5), 3125-3134.

Goswami, U., J. C. Ziegler \& U. Richardson. 2005. The Effects of Spelling Consistency on Phonological Awareness: A Comparison of English and German. Journal of experimental child psychology 92 (4), 345-365.

Gussenhoven, C. 1999. Dutch. Handbook of the International Phonetic Association: A guide to the use of the International Phonetic Alphabet. Cambridge: Cambridge University Press.

Hommel, M. 2017. Speech Perception Training as a Serious Game in the EFL Classroom. Proceedings of the Seventh ISCA workshop on Speech and Language Technology in Education Stockholm, 177-180.

Johnson, K. \& M. Babel. 2010. On the Perceptual Basis of Distinctive Features: Evidence from the Perception of Fricatives by Dutch and English Speakers. Journal of phonetics 38 (1), 127-136.

Kartushina, N. et al. 2015. The Effect of Phonetic Production Training with Visual Feedback on the Perception and Production of Foreign Speech Sounds. JASA 138 (2), 817-832.

Levy, E. S. \& F. F. Law. 2010. Production of French Vowels by American-English Learners of French: Language Experience, Consonantal Context, and the Perception-production Relationship. JASA 128 (3), 1290-1305.

Major, R. C. 2001. Foreign Accent: The Ontogeny and Phylogeny of Second Language Phonology. New York: Lawrence Erlbaum.

Mees, I. \& B. Collins 2003. The Phonetics of English and Dutch. Leiden: Brill.

Mines, M. A., B. F. Hanson \& J. E. Shoup 1978. Frequency of Occurrence of Phonemes in Conversational English. Language and speech 21 (3), 221-241.

Patel, T. K., M. J. Snowling \& P. F. de Jong. 2004. A Cross-linguistic Comparison of Children Learning to Read in English and Dutch. Journal of Educational Psychology 96 (4), 785. 
Rafat, Y.2011.Orthography-induced Transferin theProduction of NoviceAdultEnglish-speaking Learners of Spanish. Dissertation. University of Toronto. [Internet]. Available at: https:// tspace-library-utoronto-ca.proxy.library.uu.nl/handle/1807/31909 [12.07.2018].

Roach, P. 2004. British English: Received Pronunciation. Journal of the International Phonetic Association 34 (2), 239-245.

Rochet, B. L. 1995. Perception and Production of Second-Language Speech Sounds by Adults. In W. Strange (ed.) Speech Perception and Linguistic Experience. Timonium, MD: York Press, 379-410.

Silveira, R. 2007. The Role of Task-type and Orthography in the Production of Word-final Consonants. Revista de Estudos da Linguagem 15 (1), 143-176.

Simon, E. 2010. Phonological Transfer of Voicing and Devoicing Rules: Evidence from L1 Dutch and L2 English Conversational Speech. Language Sciences 32 (1), 63-86.

Strange, W. et al. 2001. Effects of Consonantal Context on Perceptual Assimilation of American English Vowels by Japanese Listeners. JASA 109 (4), 1691-1704.

Tyler, M. D. et al. 2014. Perceptual Assimilation and Discrimination of Non-native Vowel Contrasts. Phonetica, 71 (1), 4-21.

Wells, J. C. 1982. Accents of English, The British Isles, vol. 2. Cambridge: Cambridge University Press.

Wester, F., D. Gilbers \& W. Lowie. 2007. Substitution of Dental Fricatives in English by Dutch L2 Speakers. Language Sciences 29, 477-491.

Ziegler,J.C.\&L. Ferrand.1998.Orthography Shapes the Perception of Speech:The Consistency Effect in Auditory Word Recognition. Psychonomic Bulletin \& Review 5 (4), 683-689.

\section{SUMMARY}

\section{THE ROLE OF ORTHOGRAPHY AND PHONEME INVENTORY IN DUTCH STUDENTS' SPEECH PERCEPTION IN THE EFL CLASSROOM}

The goal of this paper is twofold: to determine whether orthography hampers students' L2 speech perception and whether, as PAM-L2 predicts, the L1 phoneme inventory influences L2 speech perception of Dutch secondary school students. First, a pilot perception test was administered to see if 'new' sounds that do not exist in the Dutch phoneme inventory are harder to perceive than 'same' sounds. Next, another perception test was created to look at whether orthography hampers Dutch students' perception of -for Dutch listeners- difficult English phonemes or phoneme clusters. In that perception test, all phoneme (cluster)s were embedded in common English words as spoken stimuli, and the written target words were sometimes words with an orthography that corresponded with the auditorily perceived word and sometimes with an orthography that differed from the auditorily perceived word. Results indicate that orthography impedes perception. Furthermore, in line with the predictions of PAM-L2, 'new' L2 sounds are harder to perceive than 'same' sounds.

KEYWORDS: perceptual learning, large phoneme inventory, Dutch, English, orthography. 


\section{APPENDIX}

Appendix A: English constituents correctly perceived on the pilot $\mathrm{P}$ and main test T1 respectively

\begin{tabular}{|c|c|c|}
\hline Onset P T1 & Nucleus P T1 & Coda P T1 \\
\hline lj/ $56 \% 96 \%$ & $/ \mathrm{p} / 34 \% 39 \%$ & $\mid \theta / 76 \% \quad 65 \%$ \\
\hline /v/ 66\% 67\% & $\mid v / 90 \% 36 \%$ & lg/ 72\% 84\% \\
\hline$|z| 90 \% 93 \%$ & |əu/44\% 81\% & $/ \mathrm{t} / 70 \% 86 \%$ \\
\hline$/ \mathrm{d} / 82 \% \quad 81 \%$ & $|\Lambda| \quad 36 \% \quad 24 \%$ & $/ \mathrm{d}_{3} / 44 \% 75 \%$ \\
\hline$/ 1 / 90 \% 80 \%$ & /I/ $82 \% \quad 98 \%$ & $|z| 46 \% 65 \%$ \\
\hline /g/78\% 99\% & /e/ $78 \% 59 \%$ & /s/ $78 \% 35 \%$ \\
\hline /f/ $56 \% 50 \%$ & |s:/ $50 \% \quad 13 \%$ & /f/ $46 \% 54 \%$ \\
\hline$/ d_{3} / 90 \% 25 \%$ & /i:/ 88\% 84\% & $/ \mathrm{t} \mathrm{g} / 64 \% \quad 76 \%$ \\
\hline /s/ 82\% 93\% & /eI/ 86\% 64\% & $/ \mathrm{k} / 88 \% 94 \%$ \\
\hline /ð/ 24\% 27\% & /u:/ $24 \% 39 \%$ & /v/ 52\% 86\% \\
\hline /r/ 74\% 95\% & /æ/ 72\% 86\% & $/ \mathrm{d} / 86 \% \quad 80 \%$ \\
\hline $\mid \theta / 36 \% \quad 62 \%$ & $62 \% 57 \%$ & $/ S / 94 \% 93 \%$ \\
\hline$/ b / 98 \% 94 \%$ & & $42 \%$ \\
\hline $71 \% \quad 74 \%$ & & |ð/ - \\
\hline & & $68 \% \quad 67 \%$ \\
\hline
\end{tabular}

ARTICLE INFO:

Original research article

Received: September 14, 2018

Revised: February 8, 2019

Accepted: February 12, 2019 